\title{
Fatty Liver Does Not Increase the Risk of Postoperative Liver Damage Following Hepatectomy
}

Yoriko Nomura ( $\nabla$ nomura_yoriko@med.kurume-u.ac.jp )

Kurume University Hospital

Toru Hisaka

Kurume University Hospital

Hisamune Sakai

Kurume University Hospital

Jun Akiba

Kurume University Hospital

Hirohisa Yano

Kurume University School of Medicine

Yoshito Akagi

Kurume University Hospital

Koji Okuda

Kurume University Hospital

\section{Research Article}

Keywords: liver steatosis, non-alcoholic fatty liver disease, hepatectomy, hepatitis, steatohepatitis

Posted Date: June 29th, 2021

DOI: https://doi.org/10.21203/rs.3.rs-644707/v1

License: (c) (i) This work is licensed under a Creative Commons Attribution 4.0 International License. Read Full License 


\section{Abstract \\ Background}

The number of patients with fatty liver due to alcohol consumption, the metabolic syndrome, non-alcoholic fatty liver disease, and non-alcoholic steatohepatitis is increasing. Because there is no consensus on the risk of hepatectomy in patients with fatty liver, this study examined the clinical outcomes of hepatectomy in fatty liver patients by evaluation their transaminase levels.

\section{Methods}

Patients $(n=164)$ who underwent hepatectomy for primary liver tumors from January 2014 to March 2019 were included in the study. They were divided into the steatohepatitis $(n=19)$, steatosis $(n=20)$, and viral hepatitis $(n=30)$ groups. Serum values of aspartate aminotransferase (AST), alanine transaminase (ALT), total bilirubin (TB), white blood cells, and platelets level and the prothrombin time (PT) were compared before and immediately after surgery, and on postoperative days $1-5,7$, and 10 .

\section{Results}

Overall, the AST and ALT elevation rates were higher in the control group than in the steatosis and steatohepatitis groups during postoperative days 2-7. There was no difference in postoperative hepatic dysfunction between the steatosis and steatohepatitis groups. Univariate analysis revealed significant differences in liver stiffness, operative time, mobilization, and the Pringle time. Multivariate analysis indicated low liver stiffness and a longer Pringle time as independent risk factors. Postoperative changes in the TB and albumin levels and the PT did not differ between the groups. There was no difference in the postoperative complications and hospital stay length between the groups.

\section{Conclusions}

Fatty liver does not increase the risk of postoperative liver damage following hepatectomy.

\section{Background}

In liver tumor resection, the indications for hepatectomy and the resection volume are determined according to the condition of the underlying liver disease. Previously, preoperative evaluation of liver function has mainly been performed for viral hepatitis. However recently, the incidence of liver cancer developing secondary to non-alcoholic fatty liver disease (NAFLD) has increased, and accordingly, the incidence of hepatectomy is increasing.

NAFLD, which involves triglyceride accumulation into the hepatocytes, results in a broad spectrum of liver injury and is graded based on the degree of inflammation and the degrees of fibrosis. [1] Steatohepatitis causes graft loss after liver transplantation, because it prevents postoperative liver regeneration. [2-5] Therefore, NAFLD-specific risks are also a concern in hepatectomy. Some studies have reported reductions in liver regeneration after fatty liver resection, [6] whereas others have reported no problems. $[4,7]$ Similarly, there are conflicting results regarding the risk of postoperative acute liver injury after hepatectomy. [1, 8-10]

Herein, we have focused on the factors involved in the postoperative transient elevation of transaminase level, which emphasizes the involvement of fatty liver. This study aimed to examine the clinical outcomes of performing hepatectomy in patients with fatty liver via the evaluation of transaminase.

\section{Methods}

Patients

Page 2/12 
This study was conducted under the ethical approval of the Kurume University Ethics Committee (the ethical approval number19228), and all patients provided informed consent.

Data were obtained from patients who underwent primary liver tumor resection at our hospital from January 2014 to March 2019. Patients with intrahepatic cholangiocarcinoma were excluded. Patients $(n=19)$ with steatohepatitis $(\geq 10 \%)$ were included in the steatohepatitis group and those $(n=20)$ with steatosis without inflammation (without hepatitis $B$ or $C$ infection) were included in the steatosis group. Further, 30 patients with viral hepatitis (without steatosis) were included in the control group.

\section{Extent of liver resection}

The extent of liver resection was comprehensively evaluated according to the extent of tumor progression, liver functional status, and the general condition of the patient. Tumor progression was assessed by preoperative enhanced computed tomography (CT), gadolinium ethoxybenzyl diethylenetriamine pentaacetic acid magnetic resonance imaging, and ultrasonography (US). Liver function impairment was assessed by measuring the liver biochemical parameters, determining the Child-Pugh (CP) scores, and performing indocyanine green retention tests. As a quantitative assessment of liver function, future liver remnant (FLR) volume was calculated by CT volumetry. The minimum FLR volume required was over $35 \%$ in normal livers, over $50 \%$ in mildly impaired livers, and over $60 \%$ in cirrhotic livers. In patients with normal liver function or mild liver impairment, portal vein embolization was performed when the FLR volume was insufficient.

\section{Blood analysis}

Routine blood analysis was performed at our hospital. The serum levels of aspartate transaminase (AST), alanine transaminase (ALT), albumin (Alb), total bilirubin (TB), white blood cells (WBCs), and platelets (PLT) in the peripheral blood and the prothrombin time (PT) were compared. Samples were collected within 7 days before the operation, immediately after the surgery, and on postoperative days $1-5,7$, and 10 , and their rates of change were compared using the preoperative value as a reference value.

\section{Histology}

All specimens were reviewed by at least two pathologists. The diagnosis of NAFLD was made using the Matteoni classification and NAFLD activity score (NAS). In this study, the fibrosis rate was equally classified into five stages for both viral and non-viral hepatitis (including NAFLD) according to the degree of fibrosis, as follows: F0, no fibrosis in the portal tract; F1, portal fibrosis without septa; F2, portal fibrosis with a few septa; F3, numerous septa without cirrhosis; and F4, cirrhosis.

\section{Statistical analyses}

Statistical analyses were performed using JMP 14.0 (SAS Institute Inc.). For continuous variables, comparisons were made using analysis of variance.

The Student's $t$ test, chi-square $\left(\chi^{2}\right)$ test, and Fisher's exact test were used for univariate analyses. Multivariate analyses were performed by logistic regression using odds ratios with $95 \%$ confidence intervals. Variables are expressed as means \pm standard deviation (SD) and significance was set at $\mathrm{p}<0.05$.

\section{Results}

\section{Patient characteristics}

The body mass index was higher in the steatohepatitis and steatosis groups than in the viral hepatitis group. There were significantly more patients with diabetes mellitus in the steatosis group than in the other groups; however, the hemoglobin A1c levels were controlled in all groups. No other significant differences were found in other patient characteristics (Table 1). 
Table 1

Patient characteristics

\begin{tabular}{|c|c|c|c|c|c|c|}
\hline & $\begin{array}{l}\text { Viral } \\
\text { hepatitis } \\
\text { group }\end{array}$ & $\begin{array}{l}\text { Steatohepatitis } \\
\text { group }\end{array}$ & $\begin{array}{l}\text { Steatosis } \\
\text { group }\end{array}$ & $\begin{array}{l}\text { p-value } \\
\text { (viral hepatitis } \\
\text { vs } \\
\text { steatohepatitis) }\end{array}$ & $\begin{array}{l}\text { p-value } \\
\text { (viral } \\
\text { hepatitis } \\
\text { vs } \\
\text { steatosis) }\end{array}$ & $\begin{array}{l}\text { p-value } \\
\text { (steatohepatitis } \\
\text { vs steatosis) }\end{array}$ \\
\hline $\mathrm{N}$ & 30 & 19 & 20 & & & \\
\hline Age (years) & $74.1 \pm 7.0$ & $71.6 \pm 10.3$ & $\begin{array}{l}69.0 \pm \\
11.2\end{array}$ & 0.38 & 0.06 & 0.37 \\
\hline Sex (male/female) & $23 / 7$ & $11 / 8$ & $14 / 6$ & 0.16 & 0.60 & 0.43 \\
\hline BMI $\left(\mathrm{kg} / \mathrm{m}^{2}\right)$ & $23.0 \pm 3.3$ & $27.3 \pm 6.9$ & $\begin{array}{l}26.5 \pm \\
2.9\end{array}$ & $0.002^{*}$ & $0.009 *$ & 0.60 \\
\hline Alcohol use & $14 / 16$ & $7 / 12$ & $12 / 8$ & 0.15 & 0.36 & 0.15 \\
\hline DM & $8 / 22$ & $8 / 11$ & $14 / 5$ & 0.22 & $0.001^{*}$ & 0.05 \\
\hline DM (HbA1c level) & $5.5 \pm 1.6$ & $6.3 \pm 1.8$ & $5.9 \pm 2.0$ & 0.076 & 0.32 & 0.49 \\
\hline Hypertension & $22 / 8$ & $14 / 6$ & $12 / 8$ & 0.78 & 0.49 & 0.72 \\
\hline Child-Pugh A (5/6) & $25 / 5$ & $18 / 1$ & $18 / 2$ & 0.24 & 0.51 & 0.58 \\
\hline ICG 15 (\%) & $16.9 \pm 9.1$ & $21.1 \pm 14.9$ & $\begin{array}{l}18.3 \pm \\
10.3\end{array}$ & 0.26 & 0.69 & 0.48 \\
\hline Fibroscan score $(\mathrm{kPa})$ & $13.6 \pm 10.3$ & $11.1 \pm 4.1$ & $\begin{array}{l}15.2 \pm \\
10.9\end{array}$ & 0.40 & 0.57 & 0.20 \\
\hline AFP (ng/mL) & $\begin{array}{l}69.3 \pm \\
148.7\end{array}$ & $153.8 \pm 637.2$ & $\begin{array}{l}19.9 \pm \\
30.1\end{array}$ & 0.42 & 0.63 & 0.24 \\
\hline $\mathrm{DCP}(\mathrm{mAU} / \mathrm{mL})$ & $\begin{array}{l}1385.3 \pm \\
4001\end{array}$ & $265.2 \pm 272.4$ & $\begin{array}{l}235 \pm \\
558.0\end{array}$ & 0.16 & 0.14 & 0.97 \\
\hline Tumor size (mm) & $24.1 \pm 18.6$ & $30.6 \pm 16.9$ & $\begin{array}{l}35.1 \pm \\
21.5\end{array}$ & 0.27 & 0.06 & 0.47 \\
\hline Tumor stage (I/II/III) & $13 / 13 / 3$ & $3 / 13 / 2$ & $3 / 11 / 6$ & 0.13 & 0.05 & 0.36 \\
\hline Operative time (min) & $\begin{array}{l}324.7 \pm \\
124.6\end{array}$ & $385.9 \pm 133.8$ & $\begin{array}{l}357.2 \pm \\
133.8\end{array}$ & 0.11 & 0.39 & 0.49 \\
\hline Pringle time (min) & $55.4 \pm 37.0$ & $64.2 \pm 30.6$ & $\begin{array}{l}60.7 \pm \\
39.0\end{array}$ & 0.41 & 0.61 & 0.77 \\
\hline Blood loss (ml) & $\begin{array}{l}385.4 \pm \\
457.5\end{array}$ & $557.4 \pm 568.0$ & $\begin{array}{l}513.6 \pm \\
715.1\end{array}$ & 0.31 & 0.44 & 0.81 \\
\hline $\begin{array}{l}\text { Hepatectomy } \\
\text { (partial/more than } \\
\text { sectionectomy) }\end{array}$ & $10 / 20$ & $8 / 11$ & $10 / 10$ & 0.53 & 0.24 & 0.62 \\
\hline $\begin{array}{l}\text { Operative method } \\
\text { (laparotomy/laparoscopic) }\end{array}$ & $17 / 13$ & $14 / 5$ & $14 / 6$ & 0.23 & 0.34 & 0.80 \\
\hline Resection volume & $\begin{array}{l}274.4 \pm \\
229.5\end{array}$ & $273 \pm 170.1$ & $\begin{array}{l}224.8 \pm \\
199.7\end{array}$ & 0.98 & 0.41 & 0.47 \\
\hline Resection rate (\%) & $23.7 \pm 17.2$ & $21.7 \pm 12.6$ & $\begin{array}{l}15.5 \pm \\
13.7\end{array}$ & 0.66 & 0.07 & 0.20 \\
\hline $\begin{array}{l}\text { Histological grade } \\
(\mathrm{F} ; 0 / 1 / 2 / 3 / 4)\end{array}$ & $0 / 7 / 14 / 1 / 8$ & $3 / 3 / 6 / 5$ & $5 / 5 / 1 / 7$ & 0.02 & 0.62 & 0.18 \\
\hline
\end{tabular}




\begin{tabular}{|c|c|c|c|c|c|c|}
\hline & $\begin{array}{l}\text { Viral } \\
\text { hepatitis } \\
\text { group }\end{array}$ & $\begin{array}{l}\text { Steatohepatitis } \\
\text { group }\end{array}$ & $\begin{array}{l}\text { Steatosis } \\
\text { group }\end{array}$ & $\begin{array}{l}\text { p-value } \\
\text { (viral hepatitis } \\
\text { vs } \\
\text { steatohepatitis) }\end{array}$ & $\begin{array}{l}\text { p-value } \\
\text { (viral } \\
\text { hepatitis } \\
\text { vs } \\
\text { steatosis) }\end{array}$ & $\begin{array}{l}\text { p-value } \\
\text { (steatohepatitis } \\
\text { vs steatosis) }\end{array}$ \\
\hline $\begin{array}{l}\text { Histological grade } \\
(A ; 0 / 1 / 2 / 3)\end{array}$ & $0 / 17 / 12 / 1$ & $0 / 12 / 4 / 0$ & $0 / 8 / 10 / 0$ & 0.41 & 0.47 & 0.07 \\
\hline $\begin{array}{l}\text { Histological steatotic rate } \\
(\%)\end{array}$ & 0 & $32.9 \pm 17.7$ & $\begin{array}{l}33.3 \pm \\
17.8\end{array}$ & $<0.0001$ & $<0.0001$ & 0.92 \\
\hline
\end{tabular}

AFP, alpha fetoprotein; BMI, body mass index; DCP, des-Y-carboxy prothrombin; DM, diabetes mellitus; HbA1c, glycated hemoglobin; ICG 15, indocyanine green 15 min test; N, number of patients; vs, versus

Postoperative serum AST and ALT levels before the operation were significantly higher in the steatosis and steatohepatitis groups than in the viral hepatitis group. The WBC levels were significantly higher in the steatosis group than in the viral hepatitis group. Cholinesterase was significantly lower in the viral hepatitis group than in the steatohepatitis and steatosis groups.

Biochemical examination did not reveal any significant differences between the steatosis and steatohepatitis groups (Table 2).

Table 2

Preoperative laboratory data

\begin{tabular}{|c|c|c|c|c|c|c|}
\hline & $\begin{array}{l}\text { Viral } \\
\text { hepatitis } \\
\text { group }\end{array}$ & $\begin{array}{l}\text { Steatohepatitis } \\
\text { group }\end{array}$ & $\begin{array}{l}\text { Steatosis } \\
\text { group }\end{array}$ & $\begin{array}{l}\text { p-value } \\
\text { (viral hepatitis vs } \\
\text { steatohepatitis) }\end{array}$ & $\begin{array}{l}\text { p-value } \\
\text { (viral hepatitis vs } \\
\text { steatosis) }\end{array}$ & $\begin{array}{l}\text { p-value } \\
\text { (steatohepatitis vs } \\
\text { steatosis) }\end{array}$ \\
\hline $\mathrm{N}$ & 30 & 19 & 20 & & & \\
\hline $\begin{array}{l}\text { AST level } \\
(\mathrm{U} / \mathrm{L})\end{array}$ & $\begin{array}{l}29.5 \pm \\
12.7\end{array}$ & $40.6 \pm 10.0$ & $\begin{array}{l}40.6 \pm \\
14.7\end{array}$ & 0.004 & 0.003 & 0.99 \\
\hline $\begin{array}{l}\text { ALT level } \\
(\mathrm{U} / \mathrm{L})\end{array}$ & $\begin{array}{l}22.0 \pm \\
13.4\end{array}$ & $40.3 \pm 14.5$ & $\begin{array}{l}39.2 \pm \\
16.9\end{array}$ & $<0.001$ & $<0.001$ & 0.81 \\
\hline $\begin{array}{l}\text { TB level } \\
\text { (mg/dl) }\end{array}$ & $\begin{array}{l}0.69 \pm \\
0.2\end{array}$ & $0.84 \pm 0.3$ & $\begin{array}{l}0.73 \pm \\
0.2\end{array}$ & 0.046 & 0.51 & 0.21 \\
\hline $\begin{array}{l}\text { Alb level } \\
(\mathrm{g} / \mathrm{dl})\end{array}$ & $4.0 \pm 0.4$ & $4.03 \pm 0.3$ & $4.0 \pm 0.4$ & 0.61 & 0.96 & 0.61 \\
\hline $\begin{array}{l}\text { LDH level } \\
(\mathrm{U} / \mathrm{L})\end{array}$ & $\begin{array}{l}195.7 \pm \\
43.2\end{array}$ & $194.7 \pm 32.4$ & $\begin{array}{l}184.3 \pm \\
39.0\end{array}$ & 0.94 & 0.32 & 0.41 \\
\hline $\begin{array}{l}\text { ChE level } \\
(\mathrm{U} / \mathrm{L})\end{array}$ & $\begin{array}{l}222 \pm \\
75.2\end{array}$ & $284.4 \pm 55.1$ & $\begin{array}{l}277.0 \pm \\
77.7\end{array}$ & 0.017 & 0.011 & 0.92 \\
\hline $\begin{array}{l}\text { ALP level } \\
(\mathrm{U} / \mathrm{L})\end{array}$ & $\begin{array}{l}326.5 \pm \\
361.3\end{array}$ & $233.0 \pm 60.7$ & $\begin{array}{l}276 \pm \\
100\end{array}$ & 0.20 & 0.48 & 0.59 \\
\hline PT & $\begin{array}{l}96.4 \pm \\
20.3\end{array}$ & $90.8 \pm 15.3$ & $\begin{array}{l}94.8 \pm \\
18.4\end{array}$ & 0.41 & 0.91 & 0.51 \\
\hline $\begin{array}{l}\text { WBC count } \\
(/ \mu \rrbracket)\end{array}$ & $\begin{array}{l}4966.7 \pm \\
1438\end{array}$ & $5510.5 \pm 998.3$ & $\begin{array}{l}6035 \pm \\
1391.4\end{array}$ & 0.16 & 0.007 & 0.22 \\
\hline $\begin{array}{l}\text { Plt count } \\
\left(\times 10^{3} / \mu \rrbracket\right)\end{array}$ & $\begin{array}{l}139 \pm \\
50.1\end{array}$ & $685.7 \pm 2352.8$ & $\begin{array}{l}164.4 \pm \\
31.9\end{array}$ & 0.13 & 0.94 & 0.19 \\
\hline $\begin{array}{l}\text { CRP level } \\
(\mathrm{mg} / \mathrm{dl})\end{array}$ & $\begin{array}{l}0.22 \pm \\
0.5\end{array}$ & $0.34 \pm 0.5$ & $\begin{array}{l}0.34 \pm \\
0.46\end{array}$ & 0.38 & 0.36 & 0.99 \\
\hline
\end{tabular}

Alb, albumin; ALP, alkaline phosphatase; ALT, alanine aminotransferase; AST, aspartate aminotransferase; ChE, cholinesterase; CRP, C-reactive protein; LDH, lactate dehydrogenase; N, number of patients; PIt, platelet; PT, prothrombin time; TB, total bilirubin; vs., versus; WBC, white blood cell 


\section{Postoperative changes}

The serum AST and ALT elevation rates remained significantly higher in the viral hepatitis group than in the steatosis and steatohepatitis groups during postoperative days 2-7. However, the TB, PT, and PLT values were not significantly different between the three groups. The postoperative WBC elevation rates remained significantly higher in the steatohepatitis group (Fig. 1). All patients were discharged from the hospital without significant postoperative complications or a markedly prolonged hospital stay (Table 3).

Table 3

Postoperative course and complications

\begin{tabular}{|c|c|c|c|c|c|c|}
\hline & $\begin{array}{l}\text { Viral } \\
\text { hepatitis } \\
\text { group }\end{array}$ & $\begin{array}{l}\text { Steatohepatitis } \\
\text { Group }\end{array}$ & $\begin{array}{l}\text { Steatosis } \\
\text { group }\end{array}$ & $\begin{array}{l}\text { p-value } \\
\text { (viral hepatitis } \\
\text { vs } \\
\text { steatohepatitis) }\end{array}$ & $\begin{array}{l}\text { p-value } \\
\text { (viral } \\
\text { hepatitis vs } \\
\text { steatosis) }\end{array}$ & $\begin{array}{l}\text { p-value } \\
\text { (steatohepatitis vs } \\
\text { steatosis) }\end{array}$ \\
\hline$N$ & 30 & 19 & 20 & & & \\
\hline All complications & 6 & 2 & 4 & 0.38 & 1 & 0.41 \\
\hline Minor & 6 & 2 & 4 & 0.38 & 1 & 0.41 \\
\hline Major & 0 & 0 & 0 & & & \\
\hline PHLF & 2 & 3 & 0 & 0.30 & 0.24 & 0.07 \\
\hline $\begin{array}{l}\text { Transfusion during } \\
\text { the operation }\end{array}$ & 2 & 3 & 1 & 0.30 & 0.81 & 0.27 \\
\hline $\begin{array}{l}\text { Postoperative } \\
\text { bleeding (ml) }\end{array}$ & 0 & 0 & 0 & & & \\
\hline Ascites & 0 & 1 & 0 & 0.20 & & 0.30 \\
\hline Bile leakage & 2 & 0 & 1 & 0.25 & 0.81 & 0.32 \\
\hline PVT & 4 & 0 & 3 & 0.10 & 0.87 & 0.08 \\
\hline SSI & 0 & 1 & 0 & 0.20 & & 0.30 \\
\hline Abdominal abscess & 0 & 0 & 0 & & & \\
\hline $\begin{array}{l}\text { Pulmonary } \\
\text { complication }\end{array}$ & 0 & 0 & 0 & & & \\
\hline $\begin{array}{l}\text { Cardiac } \\
\text { complication }\end{array}$ & 0 & 0 & 0 & & & \\
\hline Renal failure & 0 & 0 & 0 & & & \\
\hline $\begin{array}{l}\text { Hospital stay } \\
\text { (days) }\end{array}$ & $15.9 \pm 11.4$ & $15.2 \pm 8.4$ & $\begin{array}{l}12.4 \pm \\
6.3\end{array}$ & 0.80 & 0.20 & 0.35 \\
\hline
\end{tabular}

Minor, Clavien-Dindo classification less than grade $₫$; Major, Clavien-Dindo classification grade $\Downarrow$ or higher; N, number of patients; PHLF, post-hepatectomy liver failure based on the International Study Group of Liver Surgery criteria; PVT, portal vein thrombus; SSI, surgical site infection; vs., versus

\section{Univariate analysis of the effect of each factor on postoperative transaminase}

Table 4 shows the effect of several factors associated with postoperative peak ALT elevation rate (postoperative peak ALT/preoperative ALT). The liver stiffness, as measured by transient elastography (Fibroscan, Echosens), was significantly lower in the high ALT group (postoperative peak ALT/ preoperative ALT > 8) than in the low ALT group (postoperative peak ALT/ preoperative ALT < $)(p=0.0176)$. The operative time $(p=0.0036)$ and the Pringle time $(p=0.0012)$ were longer in the high ALT 
group than in the low ALT group. Additionally, there were significantly more cases of mobilization (as a surgical method) in the high ALT group than in the low ALT group $(p=0.0475)$.

Table 4

Results of the univariate analysis of the factor on the postoperative peak ALT elevation rate

\begin{tabular}{|c|c|c|c|}
\hline & $\begin{array}{l}\text { Peak ALT/preoperative ALT } \\
>8\end{array}$ & $\begin{array}{l}\text { Peak ALT/preoperative ALT } \\
<8\end{array}$ & p-value \\
\hline Age (years) & $72.2 \pm 9.5$ & $71.7 \pm 9.5$ & 0.81 \\
\hline Sex (male/female) & $26 / 5$ & $22 / 16$ & $0.019 *$ \\
\hline $\mathrm{BMI}\left(\mathrm{kg} / \mathrm{m}^{2}\right)$ & $24.6 \pm 3.0$ & $25.7 \pm 5.9$ & 0.33 \\
\hline DM (HbA1c level) & $5.7 \pm 1.7$ & $5.9 \pm 1.9$ & 0.54 \\
\hline HT & $21 / 8$ & $26 / 10$ & 0.98 \\
\hline ICG $15(\%)$ & $15.6 \pm 7.1$ & $20.7 \pm 13.3$ & 0.09 \\
\hline Tumor size (mm) & $331.9 \pm 19.7$ & $27.3 \pm 19.1$ & 0.35 \\
\hline Tumor stage (I/II/III) & $5 / 18 / 7$ & $14 / 19 / 4$ & 0.11 \\
\hline Hepatectomy (partial/more than sectionectomy) & $9 / 22$ & $19 / 19$ & 0.08 \\
\hline $\begin{array}{l}\text { Operative method (laparotomy } \\
\text { /laparoscopy) }\end{array}$ & $24 / 14$ & $21 / 10$ & 0.69 \\
\hline $\operatorname{AFP}(n g / m L)$ & $58.3 \pm 133.9$ & $95.1 \pm 458.4$ & 0.67 \\
\hline $\mathrm{DCP}(\mathrm{mAU} / \mathrm{mL})$ & $840.9 \pm 2451.9$ & $615.0 \pm 2801.3$ & 0.73 \\
\hline Operative time (min) & $400.6 \pm 113.1$ & $310.6 \pm 131.0$ & $0.004^{*}$ \\
\hline Operative blood loss (mL) & $588.1 \pm 663.2$ & $373.4 \pm 465.1$ & 0.12 \\
\hline Resection volume (g) & $310.9 \pm 204.9$ & $217.8 \pm 196.8$ & 0.05 \\
\hline Resection rate (\%) & $24.1 \pm 14.8$ & $18.0 \pm 15.3$ & 0.10 \\
\hline Pringle time (min) & $74.3 \pm 33.5$ & $47.1 \pm 32.9$ & $0.001 *$ \\
\hline Steatotic rate (\%) & $13.9 \pm 19.8$ & $22.7 \pm 21.5$ & 0.09 \\
\hline Liver stiffness $(\mathrm{kPa})$ & $10.2 \pm 6.3$ & $15.9 \pm 10.4$ & $0.018 *$ \\
\hline Mobilization & $18 / 13$ & $13 / 25$ & $0.048^{*}$ \\
\hline
\end{tabular}

AFP, alpha fetoprotein; ALT, alanine aminotransferase; BMI, body mass index; DCP, des-y-carboxy prothrombin; DM, diabetes mellitus; HbA1c, glycated hemoglobin; HT, hypertension; ICG 15, indocyanine green 15 min test

\section{Multivariate analyses}

The effects of several factors associated with the postoperative peak ALT elevation rate (postoperative peak ALT/preoperative ALT > 8), as analyzed by multivariate analysis are shown in Table 5. Odds ratio analysis revealed that lower liver stiffness and a longer Pringle time were associated with a higher postoperative peak of ALT. The degree of steatosis had no effect on transient postoperative ALT elevation. 
Table 5

Results of the multivariate analysis of the factor on the postoperative peak ALT elevation rate

\begin{tabular}{|lllll|}
\hline & Odds ratio & $95 \% \mathrm{Cl}$ (low) & $95 \%$ Cl (high) & p-value \\
& & & & (Probability > chi-square) \\
\hline Sex (male/ female) & 2.4958 & 0.5510 & 11.305 & 0.22 \\
\hline Operative time (min) & 1.0014 & 0.09952 & 1.0076 & 0.66 \\
\hline Pringle time (min) & 1.0309 & 1.0062 & 1.0561 & $0.006^{*}$ \\
\hline Liver stiffness (Kpa) & 0.8932 & 0.8082 & 0.9822 & $0.011^{*}$ \\
\hline Mobilization of the liver during transection & 2.3654 & 0.2211 & 0.5957 & 0.22 \\
\hline
\end{tabular}

ALT, alanine aminotransferase; $\mathrm{Cl}$, confidence interval

\section{Discussion}

In recent years, the incidence of fatty liver caused by alcohol consumption, the metabolic syndrome, NAFLD, and non-alcoholic steatohepatitis (NASH) has increased. Additionally, the administration of irinotecan-based chemotherapeutic regimens for colorectal cancer has been shown to correlate with the development of steatohepatitis, [11-12] and it increases the need for hepatectomy to remove the metastatic carcinoma from steatotic livers. The influence of steatosis following resection of fatty liver tissue remains uncertain, despite numerous reports.

In clinical practice, elevated serum transaminase and TB levels, decreased PT, and decreased PLT count of the peak value rates are used to estimate the approximate surgical damage to the liver. Elevated serum transaminase indicates the volume of hepatocytes that were impaired during surgery, and the changes in the TB level and PT are considered to have a significant effect on liver regeneration. In this study, AST and the ALT elevation rate after hepatectomy were significantly higher in patients with viral hepatitis, and there was no significant difference between patients with steatohepatitis and steatosis. Postoperative transitions in the TB and Alb levels and the PT did not differ between the groups, and there were no significant differences in the postoperative complications and hospital stay length between the groups.

Although the transaminase level showed the most noticeable changes, ALT elevation correlated with a longer Pringle time and lower preoperative liver stiffness, and was not related to the degree of steatosis. The negative correlation between the liver stiffness value and the ALT value is consistent with a previous report that postoperative transaminase elevation was uncommon in patients with cirrhosis. Sugiyama et al. reported that a cirrhotic remnant liver, including one with marked fibrosis, may release smaller amounts of aminotransferase as compared to normal livers after warm ischemia-reperfusion (IR). [13] They observed the presence of collateral circulation and suggested that the absence of portal congestion in patients with cirrhotic livers may explain the improved tolerance to the Pringle maneuver. There were no differences in the postoperative course, including the complication rate, post-hepatectomy liver failure rate, [14] and length of hospital stay after surgery between patients with viral hepatitis, steatosis, and steatohepatitis.

However, hepatic steatosis is reported to be a risk factor for postoperative graft dysfunction in transplantation. [2, 15] In cases of transplantation, macrovesicular steatosis affecting more than $30 \%$ of the hepatocytes which is thought to be associated with the metabolic syndrome and alcohol abuse,[16] was reported to be associated with an increased risk of primary graft dysfunction and graft loss due to IR injury. [2-3, 5, 15, 17-18] Macrovesicular steatosis, which is characterized by intracellular lipid accumulation and increases in the hepatocyte volume, leads to obstruction of the adjacent sinusoid spaces, and increasing vascular resistance in the hepatic microcirculation leads to mitochondrial dysfunction during reperfusion. [16, 19-20]

Generally cold IR ins used in transplantation, while warm IR is used in hepatectomy. There are fundamental differences between warm and cold IR. Warm IR injury is caused by inflow occlusion during transection of the liver and damages the hepatocytes, while cold IR injury damages liver the sinusoidal endothelial cells (LSEC). [21-23] Some studies have reported that liver 
regeneration requires increased expression of the hepatocyte growth factor by the LSECs and increased LSEC proliferation. [4, 24-25] Therefore, liver regeneration is suppressed by cold IR.

Most patients in this study had serum blood test abnormalities, which improved to normal ranges by the fifth or seventh postoperative day. They were discharged without significant postoperative complications, long-term hospital admission, or death from postoperative liver failure.

This study was not without limitations. The number of hepatectomies performed in patients with cirrhosis was small and the Pringle time seemed to have been short. Thus, it is necessary to perform further studies to determine both the effects of hepatectomy on fatty liver and to determine the volume of tissue that can be safely excised from patients with fatty liver.

\section{Conclusion}

In conclusion, due to changes in blood chemistry tests results and the frequency of postoperative complications following hepatectomy in patients with NAFLD and viral hepatitis, it is likely that the indication criteria for liver resection and the resection volume will be similar when determined using existing preoperative liver function assessments. We found that compared to viral hepatitis, fatty liver does not increase the risk of postoperative liver damage after hepatectomy, thereby highlighting the potential for patients with fatty liver to undergo hepatectomy when necessary, without the added risk of adverse outcomes.

\section{Abbreviations}

AST, aspartate aminotransferase; ALT, alanine transaminase; TB, total bilirubin; PT, prothrombin time; WBC, white blood cell; NAFLD, non-alcoholic fatty liver disease; CT, computed tomography; Gd-EOB-MRI, gadolinium ethoxybenzyl diethylenetriamine pentacetic acid magnetic resonance imaging; US, ultrasonography; CP, Child-Pugh; FLR, future liver remnant; NAS, non-alcoholic fatty liver disease activity score; BMI, body mass index; IR, ischemia reperfusion; LSCE, liver sinusoidal endothelial cells

\section{Declarations}

\section{Ethics approval and consent to participate}

Written informed consent was obtained from the patient for publication of this case report and the accompanying images. A copy of the written consent is available for review by the Editor-in-Chief of this journal on request. This study was reviewed and approved by the Ethics Committee of the Kurume University Hospital (the ethical approval number-19228).

\section{Consent for publication}

Written informed consent was obtained from the patient and her family for the publication of this report and any accompanying images. A copy of the written consent is available for review by the Editor-in-Chief of this journal.

\section{Availability of data and materials}

All data generated or analyzed during this study are included in this published article.

\section{Competing interests}

The authors declare that they have no competing interests.

\section{Funding}

This study had no funding sources.

\section{Authors' contributions}


YN collected the data and wrote the manuscript. HS and TH provided instructions for surgery. YN also performed the preoperative examination and diagnosis. JA and HY made histological diagnoses. YA and KO contributed to the study concept and review of the final manuscript. All authors read and approved the final manuscript.

\section{Acknowledgements}

We would like to thank Editage (www.editage.jp) for English language editing.

\section{References}

1. Koh YX, Tan HJ, Liew YX, Syn N, Teo JY, Lee SY, Goh BKP, Goh GBB, Chan CY: Liver Resection for Nonalcoholic Fatty Liver Disease-Associated Hepatocellular Carcinoma. J Am Coll Surg 2019, 229(5):467 - 78.e1.

2. Fujii Y, Kawamura N, Zaitsu M, Watanabe M, Goto R, Kamiyama T, Taketomi A, Shimamura T: Outcome of Living-Donor Liver Transplantation Using Grafts from Donors Treated for Fatty Liver. Ann Transplant 2020, 25:e920677.

3. Pamecha V, Bharathy KGS, Mahansaria SS, Sinha PK, Rastogi A, Sasturkar SV: "No go" donor hepatectomy in living-donor liver transplantation. Hepatol Int 2018, 12(1):67-74.

4. Garnol T, Kučera O, Staňková P, Lotková H, Červinková Z: Does Simple Steatosis Affect Liver Regeneration after Partial Hepatectomy in Rats? Acta Medica (Hradec Kralove) 2016, 59(2):35-42.

5. Kalisvaart M, de Haan JE, Polak WG, J NMI, Gommers D, Metselaar HJ, de Jonge J: Onset of Donor Warm Ischemia Time in Donation After Circulatory Death Liver Transplantation: Hypotension or Hypoxia? Liver Transpl 2018, 24(8):1001-10.

6. Picard C, Lambotte L, Starkel P, Sempoux C, Saliez A, Van den Berge V, Horsmans Y: Steatosis is not sufficient to cause an impaired regenerative response after partial hepatectomy in rats. J Hepatol 2002, 36(5):645-52.

7. Rao MS, Papreddy K, Abecassis M, Hashimoto $\mathrm{T}$ : Regeneration of liver with marked fatty change following partial hepatectomy in rats. Dig Dis Sci 2001, 46(9):1821-6.

8. de Meijer VE, Kalish BT, Puder M, ljzermans JN: Systematic review and meta-analysis of steatosis as a risk factor in major hepatic resection. Br J Surg 2010, 97(9):1331-9.

9. McCormack L, Petrowsky H, Jochum W, Furrer K, Clavien PA: Hepatic steatosis is a risk factor for postoperative complications after major hepatectomy: a matched case-control study. Ann Surg 2007, 245(6):923-30.

10. Kele PG, van der Jagt EJ, Gouw AS, Lisman T, Porte RJ, de Boer MT: The impact of hepatic steatosis on liver regeneration after partial hepatectomy. Liver Int 2013, 33(3):469-75.

11. Gomez D, Malik HZ, Bonney GK, Wong V, Toogood GJ, Lodge JP, Prasad KR: Steatosis predicts postoperative morbidity following hepatic resection for colorectal metastasis. Br J Surg 2007, 94(11):1395-402.

12. Zhao J, van Mierlo KMC, Gomez-Ramirez J, Kim H, Pilgrim CHC, Pessaux P et al: Systematic review of the influence of chemotherapy-associated liver injury on outcome after partial hepatectomy for colorectal liver metastases. Br J Surg 2017, 104(8):990-1002.

13. Sugiyama Y, Ishizaki Y, Imamura H, Sugo H, Yoshimoto J, Kawasaki S: Effects of intermittent Pringle's manoeuvre on cirrhotic compared with normal liver. Br J Surg 2010, 97(7):1062-9.

14. Rahbari NN, Garden OJ, Padbury R, Brooke-Smith M, Crawford M, Adam R et al: Posthepatectomy liver failure: a definition and grading by the International Study Group of Liver Surgery (ISGLS). Surgery 2011, 149(5):713-24.

15. Novruzov N, Bayramov N, Mammadov E: Preoperative Evaluation of Liver Parenchyma of Potential Donors in Living Donor Liver Transplantation. Transplant Proc 2019, 51(7):2379-82.

16. Chu MJ, Hickey AJ, Phillips AR, Bartlett AS: The impact of hepatic steatosis on hepatic ischemia-reperfusion injury in experimental studies: a systematic review. Biomed Res Int 2013, 2013:192029.

17. Tevar AD, Clarke CN, Schuster R, Wang J, Edwards MJ, Lentsch AB: The effect of hepatic ischemia reperfusion injury in a murine model of nonalcoholic steatohepatitis. J Surg Res 2011, 169(1):e7-14.

18. Nativ NI, Maguire TJ, Yarmush G, Brasaemle DL, Henry SD, Guarrera JV, Berthiaume F, Yarmush ML: Liver defatting: an alternative approach to enable steatotic liver transplantation. Am J Transplant 2012, 12(12):3176-83. 
19. Acosta D, Wenzel DG: Injury produced by free fatty acids to lysosomes and mitochondria in cultured heart muscle and endothelial cells. Atherosclerosis 1974, 20(3):417-26.

20. Trauner M, Arrese M, Wagner M: Fatty liver and lipotoxicity. Biochim Biophys Acta 2010, 1801(3):299-310.

21. Jawad R, D'Souza M, Selenius LA, Lundgren MW, Danielsson O, Nowak G, Bjornstedt M, Isaksson B: Morphological alterations and redox changes associated with hepatic warm ischemia-reperfusion injury. World J Hepatol 2017, 9(34):1261-69.

22. Mendes-Braz M, Elias-Miró M, Jiménez-Castro MB, Casillas-Ramírez A, Ramalho FS, Peralta C: The current state of knowledge of hepatic ischemia-reperfusion injury based on its study in experimental models. J Biomed Biotechnol 2012, 2012:298657.

23. Hide D, Warren A, Fernandez-Iglesias A, Maeso-Diaz R, Peralta C, Le Couteur DG, Bosch J, Cogger VC, Gracia-Sancho J: Ischemia/Reperfusion Injury in the Aged Liver: The Importance of the Sinusoidal Endothelium in Developing Therapeutic Strategies for the Elderly. J Gerontol A Biol Sci Med Sci 2020, 75(2):268-77.

24. Wang L, Wang X, Xie G, Wang L, Hill CK, DeLeve LD: Liver sinusoidal endothelial cell progenitor cells promote liver regeneration in rats. J Clin Invest 2012, 122(4):1567-73.

25. Haldrup D, Heebøll S, Thomsen KL, Andersen KJ, Meier M, Mortensen FV, Nyengaard JR, Hamilton-Dutoit S, Grønbæk H: Preserved liver regeneration capacity after partial hepatectomy in rats with non-alcoholic steatohepatitis. World $\mathrm{J}$ Hepatol 2018, 10(1):8-21.

\section{Figures}



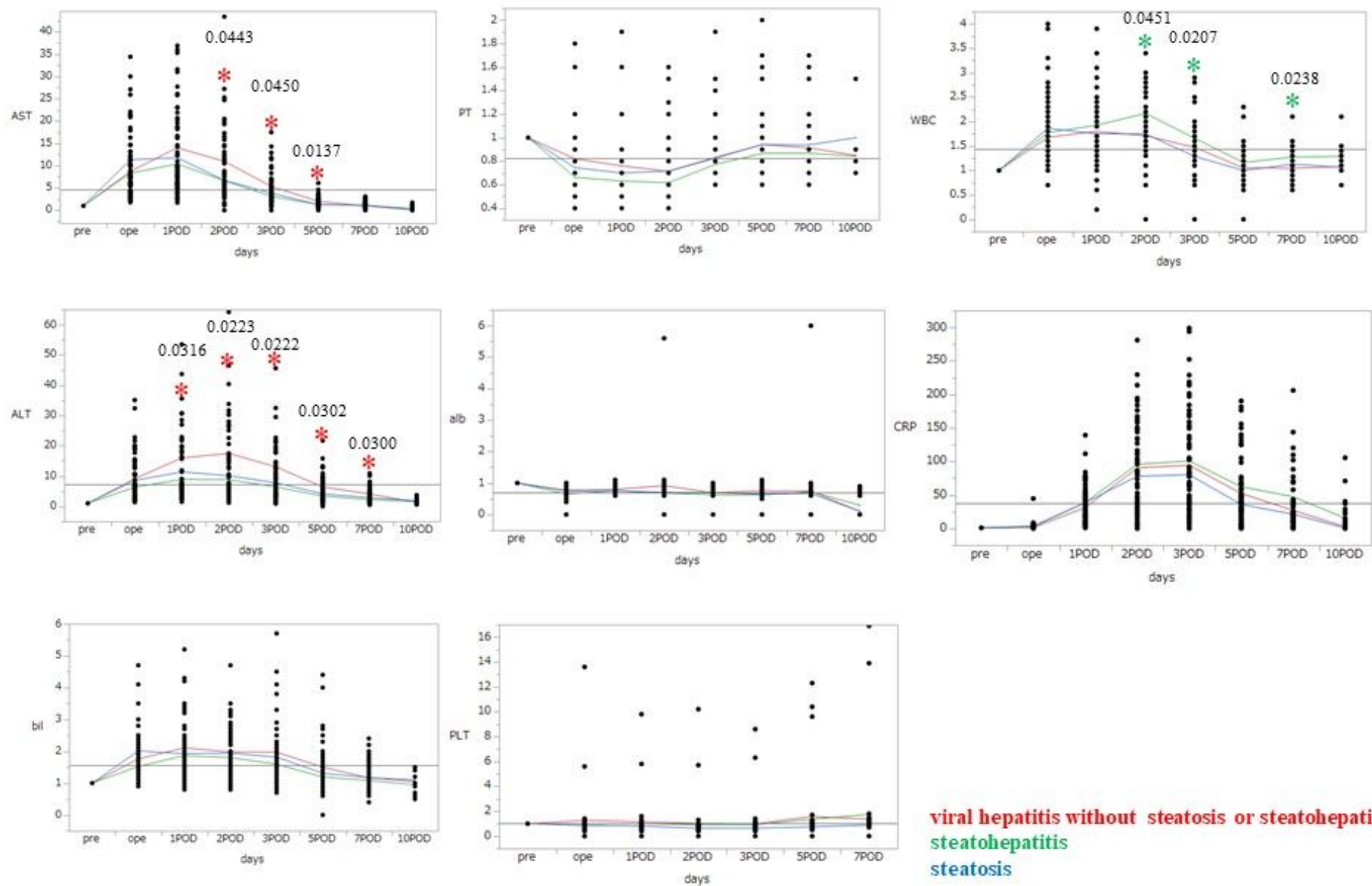

viral hepatitis without steatosis or steatohepatitis steatohepatitis steatosis

\section{Figure 1}

Changes in the postoperative serum biochemistry test results Elevation rates of AST, ALT, bil, PT, alb, plt, WBCs, and CRP were measured in the serum of patients from each group. The serum AST and ALT elevation rates remain significantly higher in the viral hepatitis group than in the other groups from day 2 to day 5 after surgery. In the steatohepatitis group, the high postoperative WBC rate remains significant. ALT, alanine transaminase; AST, aspartate aminotransferase; bil, total bilirubin; prothrombin time, PT; alb, albumin; WBC, white blood cell; C-reactive protein, CRP * indicates $p<0.05$. 